\title{
HUBUNGAN EPISIOTOMI TERHADAP INKONTINENSI URIN: SUATU STUDI EPIDEMIOLOGI
}

\author{
Novita Sari ${ }^{1}$, Edi Patmini ${ }^{2}$, Agung Nugroho ${ }^{3}$, Muhammad Nurhadi Rahman ${ }^{4}$
}

\begin{abstract}
Background:The mortality rate of urinary incontinence is low but it greatly affects a person's quality of life as can cause embarrassment and discomfort. Consequently it affects psychosocial impact of patient. Urinary incontinence 2-3 times more often experienced by women in comparison with men because of trauma risk to the connective tissue, muscle, and nerve during childbirth.
\end{abstract}

Objective: To assess association between episiotomy and nonepisiotomy vaginal delivery method on urinary incontinence among postpartum woman.

Method: A cross sectional study was conducted toward women with post vaginal delivery in Bantul Hospital during the period of March-August 2014. After considering the inclusion and exclusion criteria, there were 95 women included in the study ( 44 women with episiotomy vaginal delivery and 51 women with nonepisiotomy vaginal delivery). Questionnaire for Urinary Incontinence Diagnosis (QUID)was administered to measure urinary incontinence in postpartum women. Data were analyzed using SPSS software version 19.

Result and Discussion: The occurrence of urinary incontinence in this research was $45.3 \%$, among these $39.5 \%$ were women with episiotomy vaginal delivery, and $60.5 \%$ were women with nonepisiotomy vaginal delivery method $(p=0.228$ and $R P=0.76)$.

Conclusion: Urinary incontinence among postpartum women is not significantly different among women who delivered with episiotomy and non episiotomy.

Keyword: Urinary incontinence, vaginal delivery, episiotomy, nonepisiotomy

\begin{abstract}
ABSTRAK
Latar Belakang:Inkontinensi urin bukan masalah yang mematikan tetapi inkontinensi urin mempengaruhi kualitas hidup seseorang karena menimbulkan rasa malu dan tidak nyaman, sehingga memberikan dampak psikososial pada pasien inkontinensi urin. Inkontinensi urin 2-3 kali lebih sering dialami oleh wanita dibandingkan dengan pria karena adanya risiko terjadinya trauma pada jaringan ikat, otot, dan cedera saraf saat melakukan persalinan.

Tujuan: Mengetahui hubungan antara persalinan vaginal dengan tindakan episiotomi dan nonepisiotomi terhadap kejadian inkontinensi urin pada wanita postpartum.

Metode: Penelitian ini menggunakan desain Cross Sectional dengan 44 subjek pada kelompok persalinan vaginal episiotomi dan 51 subjek pada kelompok persalinan vaginal nonepisiotomi. Kuesioner QUID (Questionnaire for Urinary Incontinence Diagnosis) digunakan untuk mengukur inkontinensi urin pada wanita postpartum. Data kemudian dianalisis menggunakan software SPSS versi 19.
\end{abstract}

Mahasiswa S1 Pendidikan Dokter Fakultas Kedokteran UGM

2,4 Bagian Obstetri dan Ginekologi, Fakultas Kedokteran UGM / RSUP Dr. Sardjito

3 Bagian Kesehatan Ibu dan Anak, Ilmu Kesehatan Masyarakat, Fakultas Kedokteran UGM 
Hasil:Angka kejadian inkontinensi urin pada subjek penelitian yaitu $45,3 \%$, sedangkan pada kelompok persalinan vaginal episiotomi 39,5\% dan persalinan vaginal nonepisiotomi 60,5\% ( $p=0,228$ dan $R P=0,76$ ). Kesimpulan:Tidak ada hubungan yang signifikan antara persalinan vaginal dengan tindakan episiotomi dan nonepisiotomi terhadap terjadinya inkontienesi urin postpartum.

Kata kunci:Inkontinensi urin, persalinan vaginal, episiotomy dan nonepisiotomi.

\section{PENDAHULUAN}

Inkontinensi urin merupakan masalah kesehatan masyarakat yang serius di antara perempuan. ${ }^{1}$ Inkontinensi urin dapat mempengaruhi kualitas hidup seorang wanita karena menimbulkan rasa malu dan tidak nyaman, sehingga memberikan dampak psikososial pada pasien inkontinensi urin. Hal ini juga menyebabkan seseorang cenderung mengurung diri dan mengurangi sosialisasi dengan masyarakat yang ada disekitarnya. Inkontinensi urin juga dapat menyebabkan hasrat seksual seseorang mengalami penurunan dan mengurangi aktivitas seksual. $^{2}$

Penelitian yang dilakukan oleh Findik et al. melaporkan bahwa kejadian inkontinensi urin dipengaruhi oleh faktor usia dan paritas. Pada penelitiannya dikemukakan inkontinensi urin meningkat pada usia $>30$ tahun $(77,3 \%)$ dan multipara (72,3\%). ${ }^{3}$ Penelitian yang dilakukan oleh Liu et al. mengemukakan adanya perbedaan prevalensi inkontinensi urin pada kelompok persalinan vaginal episiotomi (35\%) dengan kelompok persalinan vaginal nonepisiotomi (53,4\%). Kejadian inkontinensi urin meningkat seiring bertambahnya usia dan lebih sering terjadi pada wanita. Risiko inkontinensi urin meningkat pada perempuan dengan nilai indeks massa tubuh yang lebih besar, riwayat histerektomi, infeksi urin dan trauma perineum. ${ }^{4}$

\section{METODE}

Penelitian potong lintang ini dilakukan di RSUD Panembahan Senopati Bantul dengan mengunakan data primer yang didapat dari kuesioner. Populasi pada penelitian ini adalah pasien pascasalin (persalinan vaginal) pada bulan Maret-Agustus 2014. Total subjek penelitian berjumlah 95 orang yang dipilih dengan teknik purposive sampling dan memenuhi kriteria inklusi.

Kriteria inklusi yaitu pasien yang melahirkan secara vaginal 3-6 bulan yang lalu di RSUD Penembahan Senopati Bantul, berusia 1650 tahun, dan bersedia ikut dalam penelitian dengan menandatangani informed consent. Kriteria eksklusi yaitu pasien yang melakukan persalinan dengan bantuan vakum atau forcep, riwayat penyakit genital, bayi gemelli dan data tidak lengkap.

Pengumpulan data dilakukan melalui pengisian kuesioner data demografi dan Questionnaire for Urinary Incontinence Diagnosis (QUID) oleh subjek. ${ }^{5}$ Kuesioner QUID yang telah diadaptasi dalam Bahasa Indonesia terdiri dari enam pertanyaan yang mencakup tiga tipe inkontinensi urin yaitu stress, urge dan campuran. Alasan menggunakan kuesioner QUID adalah kuesioner tersebut telah lulus uji validasi, sudah diadaptasi dalam Bahasa Indonesia dan mencakup tiga tipe inkontinensi urin.

QUID berupa kuesioner yang terdiri dari enam pertanyaan mengenai kapan waktu keluarnya urin tanpa terkendali. Tiap pertanyaan memiliki enam 
jawaban yang masing-masing memiliki nilai. Skor maksimum adalah 30. Subjek dikatakan memiliki inkontinensi urin tipe stres jika memiliki nilai tiga, empat atau lima pada pertanyaan nomor satu, dua dan tiga. Inkontinensi urin tipe urge jika subjek memiliki nilai tiga, empat atau lima pada pertanyaan nomor empat, lima dan enam. Data yang didapatkan akan berbentuk dua kategori, yaitu mengalami inkontinensi urin dan tidak inkontinensi urin. Skala yang digunakan adalah skala nominal dan hubungan antar variabel diuji dengan Chi Square melalui SPSS versi 19.

\section{HASIL DAN PEMBAHASAN}

Dari data kunjungan atau registrasi didapatkan data persalinan pada bulan MaretAgustus 2014 di RSUD Panembahan Senopati Bantul sebanyak 1207 orang. Dari 1207 orang hanya 194 orang yang berhasil dikunjungi. Dari hasil kunjungan terdapat 95 orang yang masuk kriteria inklusi, yaitu 44 subjek pada kelompok persalinan vaginal episiotomy dan 51 subjek kelompok persalinan vaginal nonepisiotomi.

Karakteristik umum subjek penelitian ditunjukan pada tabel 1 .

Usia subjek paling muda yaitu usia 16 tahun $(1,1 \%)$ dan paling tua 44 tahun $(1,1 \%)$, sebagian besar subjek penelitian masuk ke dalam kelompok usia 26-30 tahun yaitu 29 orang (30,5\%). Sejumlah $28,4 \%$ subjek tidak menggunakan alat kontasepsi, sedangkan $71,6 \%$ subjek menggunakan alat kontrasepsi. Berdasarkan hasil wawancara, alasannya antara lain suami bekerja di luar kota atau di luar negeri, mengharapkan hamil lagi dan menggunakan metode kalender. Inkontinensi urin pada penelitian ini ditemukan pada $45,3 \%$ subjek. Dari beberapa penelitian ditemukan angka yang berbeda, antara lain sebesar $35 \%$ (Baydock et al.),14,1-68,8\% (Cerruto), 76,7\% (Findik et al.) dan 23,3\% (Liu et al.). .,3,4,6
Tabel 1. Karakteristik umum subjek penelitian

\begin{tabular}{|c|c|c|}
\hline Karakteristik & Kategori & $\begin{array}{c}\text { Jumlah } \\
\text { (\%) }\end{array}$ \\
\hline \multirow[t]{4}{*}{ Usia } & $\leq 25$ & $22(23,2)$ \\
\hline & $26-30$ & $29(30,5)$ \\
\hline & $31-35$ & $25(26,3)$ \\
\hline & $\geq 36$ & $19(20,0)$ \\
\hline Tingkat & SD & $7(7,4)$ \\
\hline \multirow[t]{3}{*}{ Pendidikan } & SMP & $25(26,3)$ \\
\hline & SMA & $53(55,8)$ \\
\hline & Perguruan Tinggi & $10(10,5)$ \\
\hline \multirow[t]{6}{*}{ Pekerjaan } & Tidak Bekerja & $57(60,0)$ \\
\hline & Pegawai Swasta & $9(9,5)$ \\
\hline & PNS & $1(1,1)$ \\
\hline & Buruh & $8(8,4)$ \\
\hline & Pedagang & $4(4,2)$ \\
\hline & Lain-lain & $16(16,8)$ \\
\hline Usia & 1-5 Tahun & $48(50,5)$ \\
\hline Pernikahan & >5 Tahun & $47(49,5)$ \\
\hline Jenis & Vaginal Episiotomi & $44(46,3)$ \\
\hline Persalinan & Vaginal Tanpa Epis & $51(53,7)$ \\
\hline Usia & 28-37 minggu & $23(24,2)$ \\
\hline Kehamilan & 38-42 minggu & $72(75,8)$ \\
\hline Alat & Tidak & $27(28,4)$ \\
\hline \multirow[t]{6}{*}{ Kontrasepsi } & Menggunakan & $53(55,8)$ \\
\hline & IUD & $1(1,1)$ \\
\hline & Pil & $1(1,1)$ \\
\hline & Sterilisasi & $9(9,5)$ \\
\hline & Suntik & $4(4,2)$ \\
\hline & Kondom & \\
\hline Jenis Kelamin & Laki-laki & $48(50,5)$ \\
\hline Bayi & Perempuan & $47(49,5)$ \\
\hline \multirow[t]{2}{*}{ Pemberian ASI } & Ya & $94(98,9)$ \\
\hline & Tidak & $1(1,1)$ \\
\hline \multirow[t]{5}{*}{ Paritas } & 1 & $35(36,8)$ \\
\hline & 2 & $42(44,2)$ \\
\hline & 3 & $13(13,7)$ \\
\hline & 4 & $4(4,2)$ \\
\hline & 5 & $1(1,1)$ \\
\hline Inkontinensi & Ya & $43(45,3)$ \\
\hline Urin & Tidak & $52(54,7)$ \\
\hline
\end{tabular}


Tabel 2. Hubungan jenis persalinan vaginal dengan Inkontinensi Urin

\begin{tabular}{|c|c|c|c|c|c|c|c|}
\hline \multirow{3}{*}{$\begin{array}{c}\text { Jenis } \\
\text { Persalinan }\end{array}$} & \multicolumn{4}{|c|}{ Inkontinensi Urin } & \multirow{3}{*}{ Total } & \multirow{3}{*}{ PR $(95 \% \mathrm{Cl})$} & \multirow{3}{*}{$p$} \\
\hline & \multicolumn{2}{|c|}{ YA } & \multicolumn{2}{|c|}{ TIDAK } & & & \\
\hline & $\mathrm{n}$ & $\%$ & $\mathrm{n}$ & $\%$ & & & \\
\hline Vaginal & 17 & 39,5 & 27 & 51,9 & 44 & & \\
\hline Episiotomi & & & & & & 0,76 & 0.228 \\
\hline $\begin{array}{l}\text { Vaginal } \\
\text { Nonepisiotomi }\end{array}$ & 26 & 60,5 & 25 & 48,1 & 51 & $(0,27-1,37)$ & $0,2<0$ \\
\hline Total & 43 & 45,3 & 52 & 54,7 & 95 & & \\
\hline
\end{tabular}

Tabel 2 menunjukkan hubungan jenis persalinan vaginal dengan timbulnya inkontinesia urin. Pada penelitian ini sebagian besar inkontinensi urin terjadi pada subjek yang melakukan persalinan vaginal tanpa episiotomi (60,5\%) dengan $\mathrm{PR}=0,76 \quad(\mathrm{Cl}=0,27-1,37)$ dan $p=0,228$. Penelitian ini serupa dengan penelitian yang dilakukan oleh Liu et al.di Shanghaidengan jumlah subjek 5433 orang. Didapatkan hasil kejadian inkontinensi urin paling tinggi pada persalinan vaginal tanpa episiotomi $(53,4 \%) p<0,01 .^{4}$

Hasil penelitian ini berbeda dengan penelitian yang dilakukan oleh Baydock et al. yang menunjukan peningkatan kejadian inkontinensi tipe urge pada subjek yang melakukan persalinan vaginal dengan episiotomi yaitu $32,4 \%(p<0,01){ }^{6}$

Penelitian ini kemungkinan mempunyai karakteristik yang sama dengan Liu et al. karena lokasi penelitian di Asia yang mempunyai karakteristik fisik dan budaya yang relatif sama. Hasil penelitian ini juga mendukung teori yang menyatakan bahwa persalinan vaginal dengan episiotomi dan SC merupakan faktor pelindung terjadinya inkontinensi urin, sedangkan persalinan vaginal tanpa episiotomi dapat menyebabkan laserasi pada jaringan pendukung pelvis jalan lahir. , $, 6,7$

\section{KESIMPULAN DAN SARAN}

Tidak ditemukan adanya hubungan yang bermakna antara persalinan vaginal dengan tindakan episiotomi dan nonepisiotomi terhadap kejadian inkontinensi urin. Persalinan vaginal nonepisiotomi dapat meningkatkan kejadian inkontinensi urin namun tidak bermakna secara statistik.

\section{DAFTAR PUSTAKA}

1. Cerruto MA, D'elia C, Aloisi A, Fabrello M, Artibani $W$, Prevalence, incidence and obstetric factors impact on female urinary incontinence in europe: a systematic review. Urologia Internationalis 2012:19.

2. Decherney AH, Nathan L, Goodwin TM, Lauter $\mathrm{N}$, Current diagnosis \& treatment obstetrics \& gynecology. $10^{\text {th }}$. Ed. United States of America: MCGraw-Hill Companies. 2007

3. Findik RB, Unluer AN, Sahin E, Bozkurt OF, Karakaya $J$, Unsal $A$, Urinary incontinence in women and its relation with pregnancy, mode of delivery, connective tissue disease and other factors. Original Papers 2012:207-213.

4. Liu B, Wang L, Huang SS, Wu Q, Wu DL, Prevalence and risk factor of urinary incontinence among chinese women in shanghai. International Journal of Clinical and Experimental Medicine 2014:686696.

5. Bradley CS, Rahn DD, Nygaard IE, Batber MD, Nager CW, Kenton KS, et al., The questionnaire for urinary incontinence diagnosis (QUID): validity and 
responsiveness to change in women undergoing non-surgical therapies for treatment of stress predominant urinary incontinence. NIH Public Access 2010; 29:727-734.

6. Baydock SA, Flood C, Schulz JA, MacDonald D, Esau $D$, Jones $S$, et al., Prevalence and risk factors for urinary fecal incontinence four months after vaginal delivery. BJOG 2009:36-41.

7. Qiu J, Lv L, Lin X, Long L, Zhu D, Xu R, et al., Body mass index, recreational physical activity and female urinary incontinence in Gansu, China. NIH Public Access 2011;159(1):224-229. 